\title{
STUDY OF AUSTEMPERED DUCTILE CAST IRON ENRICHED BY PARTICULAR RATIO OF NICKEL, MOLYBDENUM AND COPPER
}

\author{
${ }^{1}$ Regita BENDIKIENE, ${ }^{1}$ Antanas CIUPLYS, ${ }^{1}$ Ramunas CESNAVICIUS, 'ytautas GRIGAS, \\ ${ }^{1}$ Audrius JUTAS, ${ }^{2}$ Aliaksandr BAHDANOVICH, ${ }^{2}$ Dzianis MARMYSH, ${ }^{2}$ Aleh NASAN, \\ 'Liudmila SHEMET, ${ }^{2}$ Sergei SHERBAKOV \\ ${ }^{1}$ Kaunas University of Technology, Faculty of Mechanical Engineering and Design, Kaunas, Lithuania, EU, \\ regita.bendikiene@ktu.It; antanas.ciuplys@ktu.It; ramunas.cesnavicius@ktu.It; vytautas.grigas@ktu.lt; \\ audrius.jutas@ktu.It \\ ${ }^{2}$ Belarusian State University, Faculty of Mechanics and Mathematics, Department of Theoretical and Applied \\ Mechanics, Nezavisimosti ave 4, 220030 Minsk, Belarus, \\ bogal@tut.by;marmyshdenis@mail.ru; oleg.nasan@gmail.com; shemetla@yandex.ru; \\ sherbakovss@mail.ru
}

https://doi.org/10.37904/metal.2020.3444

\begin{abstract}
This research paper combines investigation of mechanical properties of austempered ductile cast iron (ADI) and comparison with standard grades of steel and cast iron. Due to the special features of both materials catsability from cast iron, and toughness from steel, ADI attracts an attention of industry and science because of economic benefits and high performance at the different application areas. Austempered ductile iron was tested on tension where unconventional behaviour was observed: with the increase of tensile strength almost to $1600 \mathrm{MPa}$ the metal became less brittle. Hardness test revealed absence of linear relation between strength and hardness, different hardness values $\sim 40 \mathrm{HRC}$ or $\sim 55 \mathrm{HRC}$ can be reached with the same tensile strength $1000-1200 \mathrm{MPa}$. After successful tensile tests the main direction of further studies was solving relevant practical wear and fatigue problems in rail-wheel system. The complex practical studies demonstrated that ADI is consistent with heat treated steels including the rail steels: required tensile strength of rail steel ranges from $1180 \mathrm{MPa}$ to $1280 \mathrm{MPa}$ when rolling surface hardness is expected to be in the range of $38 \mathrm{HRC}-44 \mathrm{HRC}$, whereas tensile strength of $A D I$ was higher, up to $1400 \mathrm{MPa}$, and hardness slightly higher than of steel, $50 \mathrm{HRC}$. Herewith the workability of frictional couple cast iron/steel $20 \mathrm{MnCr} 5 \mathrm{G}$ exceeded work performance of steel/steel system by $14 \%$. Specific properties emerged from successful ratio of three elements $\mathrm{Mo}, \mathrm{Ni}$, and $\mathrm{Cu}$, and properly chosen austenitization schedule.
\end{abstract}

Keywords: Austempered ductile iron, mechanical properties, austenitization, steel like iron

\section{INTRODUCTION}

Steel and cast iron are iron-carbon base alloys, the production of which to determines the world technical progress over the past 200 years. The extent of production of these ferrous alloys, despite the fact that there is a continuous study for their substitutes, such as special non-ferrous alloys, powder materials, polymers, composites, etc., rise steadily [1,2]. Production of both steadily increases, however, extent of cast iron casting significantly inferior to the production of steel. It can be explained by lower strength of former.

Up to the middle of the last century the only cast iron grade able to show both a high castability as well as good mechanical properties was malleable iron [3,4]. These results were achieved by graphitizing annealing performed on white cast irons. Later studies in 60's adding magnesium and cerium allowed to obtain cast irons with nodular shape graphite (ductile cast iron) and analogous mechanical properties with lower production 
cost. Ductile cast iron is a fascinating engineering material for the manufacturing of different components including wear resistant parts requiring an optimized compromise between fatigue and wear, truck suspension parts, power transmission components, stones crushers and mining components, and components of various geometrical complexity, etc. [5-7]. Austempering is the most widely used heat treatment procedure to reach excellent combination of high strength, ductility, good wear resistance and tribo-fatigue behavior. So called austempered ductile irons (ADI) in addition to low manufacturing cost, fluidity, recyclability, damping capacity, and heat conductivity are much better than of some grades of alloyed cast steels, consequently they can be considered as an economical replacement for alloyed steel and other grades of cast irons [8,9].

Mechanical properties of ADI are strongly influenced by chemical composition, austempering temperature, holding time, and quenching rate. Heat treatment cycle places significant role in resultant properties of cast iron. Such an iron has a microstructure consisting mainly of ferrite-austenite and nodular graphite particles [10]. Microstructure of ADI could be altered changing modificators and parameters of heat treatment processes.

If high wear resistance application is necessary, ADI could be considered because of its suitability to the different wear mechanisms: abrasion, adhesion, contact or sliding fatigue, tribo-fatigue, and tribo-corrosion. Introduction of carbides in ADI composition with the purpose to reinforce the matrix subjected to abrasive wear may adapt to different wear mechanisms [11], consequently existence of hard carbide particles in such a tribosystem increases the abrasion resistance however reduces the impact toughness [12].

Wheel-rail tribo-fatigue system is the physical basis of train movement on steel railways which are the nervous system of the railroads, and obviously their conditions an efficiency of whole system. The requirements for steel rails are continuously increasing, since it is necessary to transport more and more cargo (people as well) to ever longer distances with steadily increasing speeds. So, it is extremely important to analyze situation of the rails and to suggest the best materials. To succeed achieve this goal a specific scientific proposal is put forward: casting of rails made of austempered ductile cast iron. Therefore, if the mechanical properties of ductile cast iron for rails were about the same as that of steel, then well-known high-strength nodular cast iron would be incomparably better than steel in a number of service properties: wear resistance, self-lubrication, damping ability and others. To achieve this goal a specific scientific proposal is put forward: casting of rails made of austempered ductile cast iron. The point is to have such high-strength cast iron for the manufacture of rails, the mechanical properties of which at least would not be inferior to steel, i.e. steel like high-strength cast iron would be preferable. Such a austempered ductile cast iron with specific ratio of $\mathrm{Ni}, \mathrm{Mo}$, and $\mathrm{Cu}$ for potential application in rail-wheel system is under the consideration in this research paper.

\section{METHODOLOGICAL BASES}

Commercial grades of case hardening steel (20MnCr5G) and austempered ductile cast iron (ADI-1050) were selected for comparison with ADI. The chemical composition of material under the research is shown in Table 1. The former was chosen due to its suitability to manufacture the cemented parts, which require increased strength and toughness of the core, as well as high surface hardness, working under the shock loads. The lower bainite structure of the later (ADI) assures high contact fatigue strength $(1020-1260 \mathrm{MPa})$ which exceeds contact strength of carbon, alloyed, nitride and hardened steels, but stays behind case hardening steels (1260 - $1630 \mathrm{MPa})$.

Table 1 Chemical composition of material under the research

\begin{tabular}{|c|c|c|c|c|c|c|c|c|c|c|}
\hline Element & $\mathbf{C}$ & $\mathbf{S i}$ & $\mathbf{M n}$ & $\mathbf{C r}$ & $\mathbf{M o}$ & $\mathbf{N i}$ & $\mathbf{C u}$ & $\mathbf{M g}$ & $\mathbf{T i}$ & $\mathbf{F e}$ \\
\hline wt. \% & $3.5-3.7$ & $2.5-2.8$ & $0.2-0.3$ & $0.02-0.06$ & $0.4-0.6$ & $0.5-0.6$ & $1.1-1.3$ & $0.03-0.07$ & $0.01-0.12$ & Bal. \\
\hline
\end{tabular}

Austenization was used to modify properties seeking to achieve the higher mechanical strength along with steel-like ductility. This treatment requires an interrupted quenching in a salt bath with long enough duration to 
reach the desired austempering effect $[13,14]$. Treated alloy has a combination of exceptional strength and toughness, corresponding or even exceeding those of alloyed steels. The cycle of austenitization began from holding at $890^{\circ} \mathrm{C}$ for $\sim 30 \mathrm{~min}$ in a furnace. Afterwards, an isothermal heat treatment process, in which test samples were quenched in a molten salt bath of sodium and potassium nitrate salts (potassium nitrate $\mathrm{KNO}_{3}-50 \%$ GOST $19790-74$, sodium nitrate $\mathrm{NaNO}_{3}-25 \%$ GOST $4168-79$, sodium nitrite $\mathrm{NaNO}_{2}-25 \%$ GOST 19906-74). The test samples were removed from a high temperature to the quench bath within $5 \mathrm{~s}$, to ensure formation of upper or lower bainite. Austempering was done at different temperatures: $330{ }^{\circ} \mathrm{C}, 300^{\circ} \mathrm{C}$ and $270{ }^{\circ} \mathrm{C}$, in order to study the influence of the process temperature on tensile strength-ductility ratio and the evolution of microstructure. Time of the process plays significant role on the formation of structure consequently the properties of the material. If time is too short, the hardness can reach high values with low values of toughness and ductility, while if time is too long lower hardness, strength, fracture toughness and ductility exhibits. At the temperature of $330^{\circ} \mathrm{C}$ slightly more than half an hour is enough to reach necessary structure, while lowest process temperature $270^{\circ} \mathrm{C}$ requires more than $1 \mathrm{~h}[15,16]$.

Tensile test pieces were made according to the dimensions presented in Figure 1. Tensile tests were done on multifunctional servohydraulic testing machine LFV100, Walter-Bai AG, Switzerland.

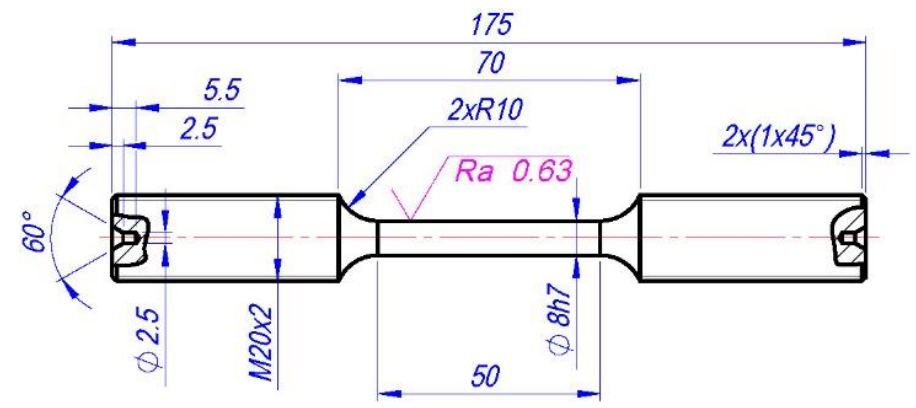

Figure 1 Dimensions of tensile test piece

Tribo-fatigue test pieces were casted according to the scheme presented in Figure 2. SI-O3 M test machine was used to study behavior of ADI in the contact with counter-specimen [16].

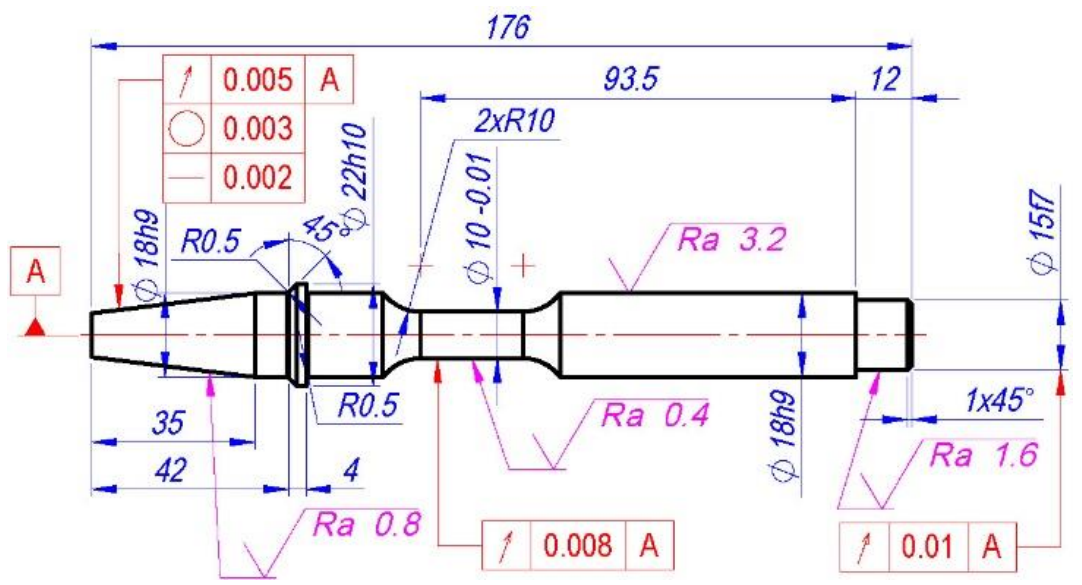

Figure 2 Dimensions of tribo-fatigue test piece

Brinell and Rockwell hardness tests were accomplished at the different stages of experiment using Universal hardness tester Verzus 750CCD. Vickers surface hardness (HV30) of the surface of the hardfacings was measured using the Vickers hardness tester Indentec 5030KV (Zwick/Roell, Germany) at the load 294.3 N (30 kgf) and the dwell time $10 \mathrm{~s}$. Ten measurements were done on each sample and the average hardness value was calculated. Analysis of microstructure was performed on MLA 10 and Carl ZeisAxio Scope A1. 


\section{RESULTS AND DISCUSSION}

The strength, hardness and fatigue of any metal can be characterized by its structure. As cast ductile iron

(Figure 3 a) has a typical bull's eye structure which is formed largely of pearlitic matrix and ferrite surrounding graphite [16].

During the austempering process in the region where two phases ferrite and austenite coexist, pearlitic matrix trasforms to austenite and the certain amount of ferrite which still is influenced by the austenitizing temperature. The austenite, gathered at the grain boundaries of ferrite, starts to grow through the ferrite grains. The result of such a growth is formation of ferritic matrix layered with carbon-enriched austenite. Further nucleation of austenite at the grain boundaries of primary ferrite leads to the enrichment and saturation of austenite with carbon, later diffusion of carbon becomes complicated causing by the end of ferrite grain growth.

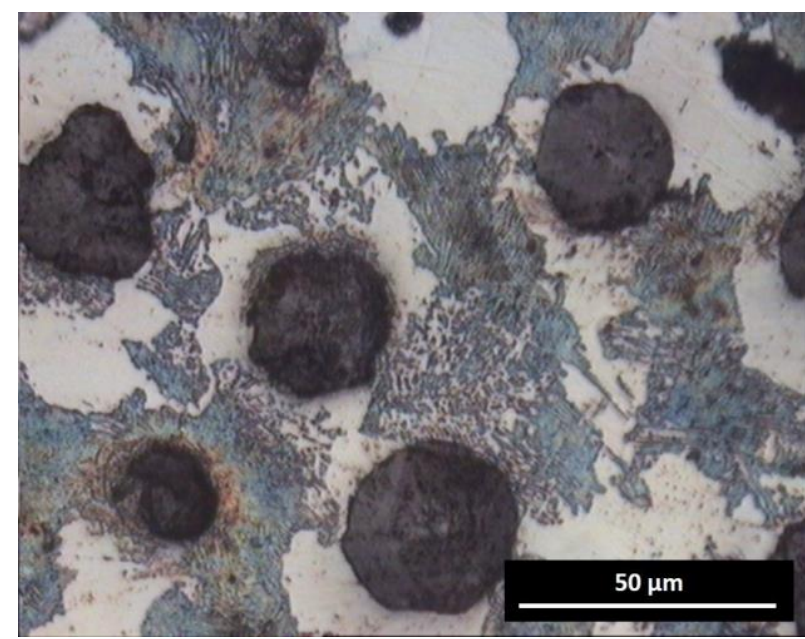

a

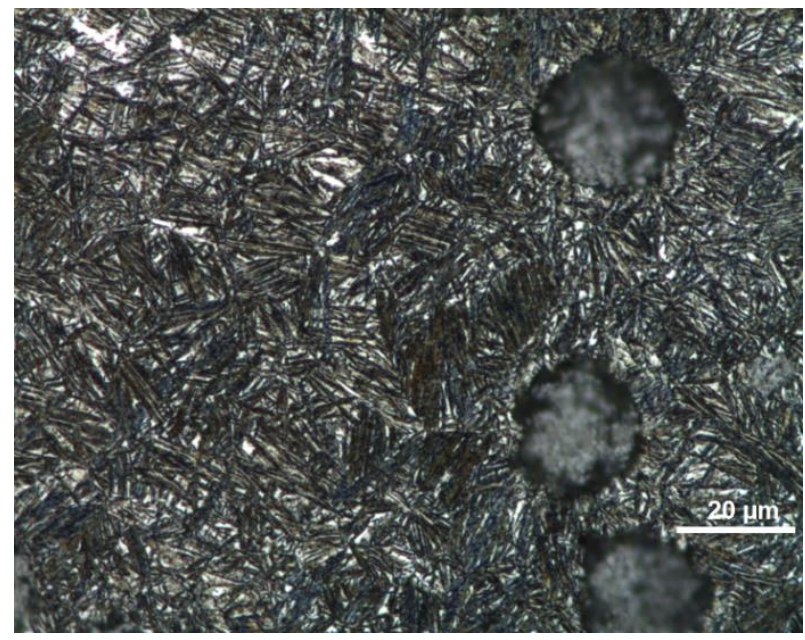

C

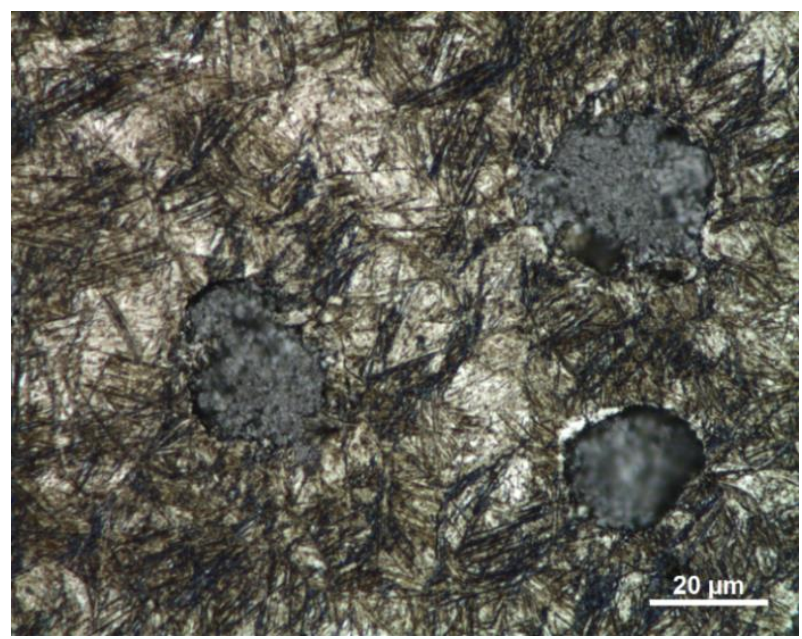

b

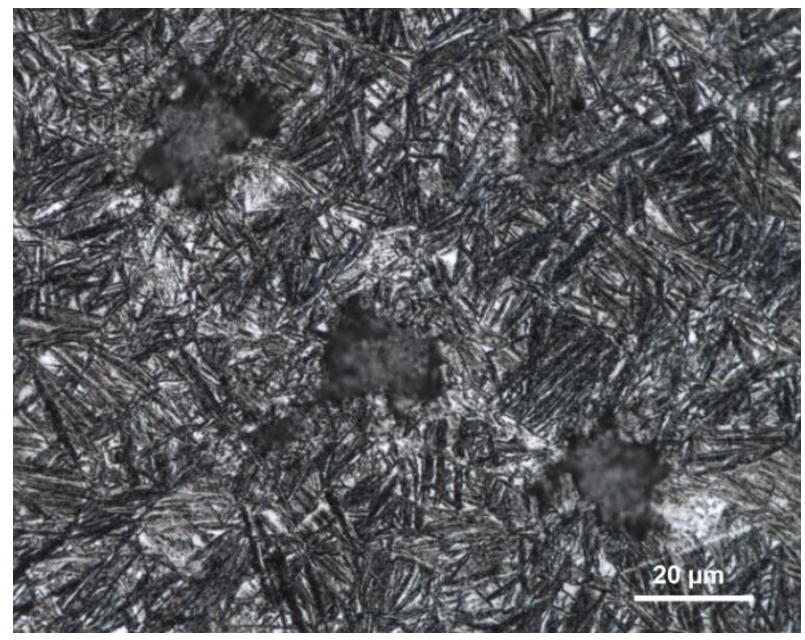

d

Figure 3 Optical views of $A D I$ : $a$ - as cast; b - austempered at $270{ }^{\circ} \mathrm{C} ; \mathrm{c}-300^{\circ} \mathrm{C} ; \mathrm{d}-330^{\circ} \mathrm{C}$

Treated at $270{ }^{\circ} \mathrm{C}$ the microstructure of samples (Figure $\mathbf{3} \mathbf{b}$ ) consist mainly of matrix of ausferrite, bainitic ferrite and graphite nodules. On increasing the austempering temperature to $300^{\circ} \mathrm{C}$ or to $330{ }^{\circ} \mathrm{C}$ (Figure $3 \mathrm{c}$ and $\mathbf{d}$ respectively) more ausferrite is formed, and its feathery needles become coarser [17]. The higher the temperatures of austempering the higher quantity of coarse ausferrite, at the same time as Lever rule says the volume of ausferrite decreases on increases the process temperature. Thus, from the images in Figure 3 it can be concluded that the structure of austempered ductile cast iron is neither bainitic, nor martensitic, nor 
ferritic-pearlitic; it is a special cast iron, which, in respect on the austempering temperature can demonstrate various and diverse structural states similar to the microstructure of steel.

Comparison of the durability limits of ADI, commercial grade of cast iron ADI-1050, and structural steel $20 \mathrm{MnCr} 5 \mathrm{G}$ are presented in Table 2.

Table 2 Durability limits of materials under the research

\begin{tabular}{|c|c|c|c|c|c|c|}
\hline \multirow{2}{*}{ Material } & \multicolumn{2}{|c|}{ Hardness (HB) } & \multicolumn{2}{c|}{$\begin{array}{c}\text { Limit of contact fatigue } \\
(\mathrm{MPa})\end{array}$} & \multicolumn{2}{c|}{$\begin{array}{c}\text { Limit of durability on tension } \\
(\mathrm{MPa})\end{array}$} \\
\cline { 2 - 7 } & $\min$ & $\max$ & $\min$ & $\max$ & $\min$ & $\max$ \\
\hline ADI-1050* & 200 & 300 & 550 & 700 & 210 & 248 \\
\hline 20MnCr5G** & 200 & 300 & 706.6 & 1123.1 & 302.6 & 370.3 \\
\hline ADI this paper & 320 & 360 & 900 & 1050 & 270 & 310 \\
\hline * ISO 17804/JS/1050-6/S; ** DIN EN 10083-3-2009, ISO 683-2:2016 & \\
\hline
\end{tabular}

It is clearly seen that $\mathrm{ADI}$ with specific ratio of $\mathrm{Ni}, \mathrm{Mo}$, and $\mathrm{Cu}$ is a very successful competitor for standard grade austempered cast iron and even overtakes alloyed steel. Comparing cast iron and steel by loading capacity and durability, the output will be similar.

The loading capacity of $\mathrm{FN}=1100 \mathrm{~N}$ and durability (number of loading cycles $\mathrm{N}=1.20 \times 10^{6}$ ) with a multistage increase in load until the ultimate state is reached of $A D I$ and steel 20MnCr5G (ultimate tensile strength $\sigma_{u}=1600 \mathrm{MPa}$, hardness $700 \mathrm{HV}$, fatigue strength at the bending $640 \mathrm{MPa}$ and contact fatigue of $1270 \mathrm{MPa}$ ). ADI showed high fatigue resistance. All the tests were performed under the same frequency of $30001 / \mathrm{min}$, as the base 105 cycles longevity was used. Results showed that cyclic stresses significantly slowed process of tribo-fatigue under the given test conditions, as a result workability range was increased approximately by $14 \%$. It can be explained by the removal of thin surface layer containing primary fatigue cracks during the test out of the working zone.

Tribo-fatigue failure mechanism is related with accumulation of microplasticity, so it is assumed that it strongly depends on material hardness [11]. For homogeneous materials such as hardened or tempered steel, the hardness is a dominant property in the tribo-fatigue system, however for austempered ductile irons with complex structure (nodular graphite, retained austenite, carbide) this dependence due to the presence of different inclusions is lower. On the other hand, formation of granular carbides in the structure of MoNiCa [8] promotes an increase of abrasion wear resistance with slightly decrease of toughness. This behavior needs further studies. Ensuring the required coefficient of friction for high-loaded tribo-fatigue system is of the great practical importance, since its specific numerical value firstly causes the loss of drive power, and secondly directly affects the wear of the elements of the contact couple.

\section{CONCLUSION}

The presented study showed that austempered ductile cast iron modified with successful ratio of Ni, Mo, and $\mathrm{Cu}$ has only one serious competitor in tensile strength-ductility, tribo-fatique study: case hardening steel. ADI displayed tensile strength increase to almost $1600 \mathrm{MPa}$, what is more expected from heat treated steels. It was reached having austempering temperatures of $270^{\circ} \mathrm{C}, 300^{\circ} \mathrm{C}$, and $330 \mathrm{C}$, as a result the metal became less brittle. Hardness test showed absence of linear relation between strength and hardness of ADI, different hardness values $\sim 40 \mathrm{HRC}$ or $\sim 55 \mathrm{HRC}$ can be reached having the same tensile strength $1000-1200 \mathrm{MPa}$. Due to the different austempering temperatures optical analysis showed formation of specific structures. It was shown that $A D I$ is not inferior to high-strength steel including rail steel in terms of mechanical properties, fatigue resistance and fracture toughness. Test performed on SI-O3 M tribo-fatigue machine using small-sized models let say that the application of the ADI for rail production can lead up to $50 \%$ of wear reduction. Taking into the 
account lower cost of cast iron manufacturing it can be expected the cost of cast rails made on ADI could be by $30-50 \%$ less than the cost of the steel rails produced by rolling.

\section{ACKNOWLEDGEMENTS}

\section{This work was supported by the Research Council of Lithuania [grant number S-LB-19-6]; and performed in cooperation with the Belarusian State University.}

\section{REFERENCES}

[1] YU, Y., CHEN, Z., WEI, L., WANG, B. The low-carbon technology characteristics of china's ferrous metal industry. Journal of Cleaner Production. 2017, vol. 140, pp. 1739-1748.

[2] FENG, Ch., HUANG, J.B., WANG, M. The sustainability of China's metal industries: Features, challenges and future focuses. Resources Policy. 2019, vol. 60, pp. 215-224.

[3] LABRECQUE, C., GAGNÉ, M. Ductile iron: Fifty years of continuous development. Canadian Metallurgical Quarterly. 1998, vol. 37, pp. 343-378.

[4] IACOVIELLO, F., DI COCCO, V., BELLINI, C. Fatigue crack propagation and damaging micromechanisms in Ductile Cast Irons. International Journal of Fatigue. 2019, vol. 124, pp. 48-54.

[5] COLOMBO, D.A., DOMMARCO, R.C., BASSO, A.D. Rolling contact fatigue behavior of dual-phase austempered ductile iron. Wear. 2019, vol. 418-419, pp. 208-214.

[6] MASAGGIA, S. The development of ADI and IDI in Italy. Procedia Engineering. 2010, vol. 2, pp. 1459-1476.

[7] IANNITTI, G., RUGGIERO, A., BONORA, N., MASAGGIA, S., VENERI, F. Micromechanical modelling of constitutive behavior of austempered ductile iron (ADI) at high strain rate. Theoretical and Applied Fracture Mechanics. 2017, vol. 92, pp. 351-359.

[8] BAHDANOVICH, A., BENDIKIENE, R., CESNAVICIUS, R., CIUPLYS, A., GRIGAS, V., JUTAS, A., MARMYSH, D., MAZALEUSKI, A., NASAN, A., SHEMET, L., SHERBAKOV, S., SPAKAUSKAS, K., SOSNOVSKIY L. Research on tensile behaviour of new structural material MoNiCa. Material Science-Medziagotyra. 2019, vol. 25, no. 3, pp. 292-296.

[9] WANG, B., HE, M., BARBER, G.C., SCHALL, J.D., TAO, C., SUN, X. Rolling contact fatigue resistance of austempered ductile iron processed at various austempering holding times. Wear. 2018, vol. 398-399, pp. 41-46.

[10] ZAMMIT, A., ABELA, S., BETTS, J.C., MICHALCZEWSKI, R., KALBARCZYK, M., GRECH, M. Scuffing and rolling contact fatigue resistance of discrete laser spot hardened austempered ductile iron. Wear. 2019, vol. 422423, pp. 100-107.

[11] PEDRO, D.I., DOMMARCO, R.C. Rolling contact fatigue resistance of Carbidic Austempered Ductile Iron (CADI). Wear. 2019, vol, 418-419, pp. 94-101.

[12] LAINO, S., SIKORA, J.A., DOMMARCO, R.C. Development of wear resistant carbidic austempered ductile iron (CADI). Wear. 2008, vol. 265, pp. 1-7.

[13] SELLAMUTHU, P., HARRIS SAMUEL, D.G., DINAKARAN, D., PREMKUMAR, V.P., Li, Z., SEETHARAMAN, S. Austempered Ductile Iron (ADI): Influence of austempering temperature on microstructure, mechanical and wear properties and energy consumption. Metals. 2018, vol. 53, no. 8, pp. 1-12.

[14] ZHANG, N., ZHANG, J., LU, L., ZHANG, M., ZENG, D., SONG, Q. Wear and friction behaviour of austempered ductile iron as railway wheel material. Materials and Design. 2016, vol. 89, pp. 815-822.

[15] DIAS, J.F., RIBEIRO, G.O., CARMO, D.J., VILELA, J.J. The effect of reducing the austempering time on the fatigue properties of austempered ductile iron. Materials Science and Engineering A. 2012, vol. 556, pp. 408-413

[16] SOSNOVSKIY, L.A., BOGDANOVICH, A.V., YELOVOY, O.M., TYURIN, S.A., KOMISSAROV, V.V., SHERBAKOV, S.S. Methods and main results of Tribo-Fatigue tests. International Journal of Fatigue. 2014, vol. 66, pp. 207-219.

[17] KUMARI, U.R., RAO, P.P. Study of wear behaviour of austempered ductile iron. Journal of Materials Science. 2009, vol. 44, pp. 1082-1093. 